\title{
Characteristics of Lawyers Who are Subject to Complaints and Misconduct Findings
}

\author{
Tara Sklar, Yamna Taouk, David Studdert, Matthew Spittal, Ron Paterson, and Marie \\ Bismark*
}

Regulators of the legal profession are charged with protecting the public by ensuring lawyers are fit to practice law. However, their approach tends to be reactive and casebased, focusing on the resolution of individual complaints. Regulators generally do not seek to identify patterns and trends across their broader caseloads and the legal profession as a whole. Using administrative data routinely collected by the main regulator of the legal profession in Victoria, Australia, we characterized complaints lodged between 2005 and 2015 and the lawyers against whom they were made. We also analyzed risk factors for complaints and misconduct findings. We found that the odds of being subject to a complaint were higher among lawyers who were male, older, had trust account authority and whose legal practices were smaller, in nonurban locations, and incorporated. A deeper understanding of these risk factors could support efforts to improve professional standards and reform regulatory practices.

\section{INTRODUCTION}

The neglect of legal malpractice law contrasts strangely with the attention devoted to its big sister, medical malpractice law. The latter has received much more attention from empirical investigators, analysts and legislators. (Ramos 1996:871)

\footnotetext{
* Address correspondence to Associate Professor Marie Bismark, Melbourne School of Population and Global Health, University of Melbourne, 207 Bouverie Street, Parkville, VIC 3010, Australia, email: mbismark@unimelb.edu.au. Sklar is Professor of Health Law at James E. Rogers College of Law, University of Arizona; Taouk is Research Assistant at Melbourne School of Population and Global Health, University of Melbourne; Studdert is Professor of Law and Medicine at Stanford University; Spittal is Associate Professor at Melbourne School of Population and Global Health, University of Melbourne; Paterson is Professor of Law at Auckland University; Bismark is Associate Professor at Melbourne School of Population and Global Health, University of Melbourne.
}

The authors wish to acknowledge the Victorian Legal Services Board and Commissioner for funding this research, with particular thanks to Commissioner Michael McGarvie, Russell Daily, Maggie McNamara, Christine Bell, and Abrahim Dahdoule, for their guidance in extracting the data and interpreting the findings. We appreciate helpful comments and suggestions from David Hyman, Bill Madden, Jennifer Moore, Jordan Neyland, Christopher Robertson, Brad Wendel, Emily Taylor Poppe, Lisa Webley, and workshop participants at Melbourne Law School, New South Wales Law Society, Georgetown Law School O’Neill Institute, the 2017 Conference on Empirical Legal Studies, and the 2018 QuantLaw Conference at the University of Arizona College of Law.

This is the author manuscript accepted for publication and has undergone full peer review but has not been through the copyediting, typesetting, pagination and proofreading process, which may lead to differences between this version and the Version of Record. Please cite this article as doi: $10.1111 /$ jels.12216 
Regulators of the legal profession — such as state bars, law societies, complaint commissions, and legal services boards - are charged with upholding professional standards of practice and protecting consumers of legal services. The public and the profession expect these regulators to take timely and appropriate action in response to complaints about the conduct and performance of lawyers. However, their approach tends to be reactive and focused on the resolution of individual complaints (Parker 2004). This case-based approach, coupled with limited resources and empirical expertise, means that regulators of the legal profession typically spend little time investigating patterns and trends across their broader caseloads and the legal profession at large. This is a missed opportunity. Regulatory agencies amass valuable data on patterns of concern about large populations of practitioners that, if analyzed carefully, could yield insights to help guide and improve regulatory oversight, supervision, training and education (Bismark 2016).

Empirical quantitative research on lawyer misconduct is a growing field, but still lags behind similar efforts in the medical profession. Over the last decade a substantive body of empirical scholarship has improved medical regulators' understanding of patterns of complaints, malpractice claims, and disciplinary actions (Studdert et al. 2016; Jena et al. 2011; Rolph et al. 2007). More recently, medico-legal research has moved past large-scale descriptive studies to predictive analysis (Spittal et al. 2015). Arming regulators with an ability to identify high-risk practitioners, before they accumulate poor track records, permits more effective use of scarce regulatory resources, and may help target interventions that prevent adverse outcomes for doctors and patients.

Most empirical research on lawyer misconduct has used case studies (Abel 2008; Abel 2012) or a combination of descriptive statistics and qualitative research (Bartlett 2008; Kritzer \& Vidmar 2018) rather than analytical statistical methods. While these studies provide valuable insights into patterns of lawyer misconduct, to the best of our knowledge, no previous research has analyzed longitudinal lawyer-level data across an entire jurisdiction.

Why has quantitative research into lawyer misconduct lagged behind research into medical 
misconduct? There are three plausible explanations. First, medical misconduct is more likely than legal misconduct to pose public safety risks, trigger costly lawsuits, and capture the attention of the public and policy makers (Barton 2007). Second, legal researchers confront more serious data limitations. The limited access to high-quality caseload data has welldocumented by researchers in the United States (US), who have expressed concern that data maintained by legal regulators is fragmented and incomplete, of questionable quality, and often unavailable to researchers (Hatamyar \& Simmons 2004; Campbell \& Kollman 1999; Rhode 1985). In many jurisdictions, court rules prevent access to such data. Where data does exist, information on complaints and the register of practicing lawyers may be held by separate agencies, or only stored for limited periods of time. Third, the empirical legal researchers who are working in this field have been much more inclined to pursued qualitative research approaches based on case studies and international comparisons (Abel 2012; Levin 2012; Haller 2012; Shinnick et al. 2003; Christensen et al. 1999).

Salient similarities in the regulation of the medical and legal professions provide an opportunity for legal researchers to emulate the kinds of analyses the have been used to examine medical misconduct. Of importance to this study, regulators of both professions use a registration- and licensing-based model, as well as complaint-based regulatory oversight. In both fields, the asymmetry of information between practitioners and their clients means that it is often difficult for clients to identify of substandard practice; consequently, many complaints relate to more readily observable aspects of practice, such as costs and communication. Yet, in the absence of other more robust and transparent quality indicators, regulators in both professions remain heavily reliant on complaints as a mechanism for alerting them to individual instances of potentially substandard practice.

The goal of this study was to explore the power of large-scale legal regulatory data to advance understanding of the characteristics of lawyers who are subject to complaints and disciplinary action. We conducted our research in partnership with the Victorian Legal Services Board and Commissioner (LSBC), the statutory complaint-handler and disciplinary prosecutor for the legal profession in Victoria, Australia. 
The article proceeds as follows. Section II describes the evolution of regulation of the legal profession in Victoria, Australia, and surveys relevant empirical research on misconduct in the medical and legal literatures. Section III describes our data and methods. Section IV reports our main results. Section V discusses the risk factors for complaints that were identified in our analyses and explains the strengths and limitations of our approach. Section VI concludes.

\section{BACKGROUND}

\section{A. Regulation of Lawyers in Victoria, Australia}

Victoria is Australia's second most populous state, with nearly six million residents. The LSBC is the regulatory body charged with regulating the state's legal profession, and is accountable to the Victorian Parliament. Prior to the 1980s, lawyers in Victoria were largely self-regulated. Victoria and other Australian jurisdictions followed the United Kingdom's self-regulatory approach whereby lawyers were exposed to disciplinary action only if their professional colleagues found their conduct to be disgraceful or dishonorable (Haller 2003). The profession's control of both the investigatory and the adjudicatory phases of the process was justified by the claim that only lawyers themselves had the necessary expertise to assess and police the character and competence of their colleagues (Rueschemeyer 1983). This approach reflected a tradition of largely unfettered professional autonomy, a perception that professional ethics alone were sufficient to protect consumers, and a reluctance to recognize the rights of clients to complain about the quality of services provided (Christensen et al. 1999).

The legal profession's resistance to client-centered models of service and complaint resolution was heavily criticized in the 1970s and 1980s. Concerns about overcharging, delays, and poor communication were common. In Victoria, the most frequent client complaints at that time centered on incompetence and negligence (Haller 2003; Shinnick et al. 2003). In response to growing concerns, the Victorian Parliament passed new legislation establishing a client-focused standard for 'unsatisfactory conduct', which was defined as: “A 
lawyer or firm falling short of the standard of competence and diligence that a member of the public is entitled to expect of a reasonably competent legal practitioner or firm” (Legal Practice Act 1996, ss. 137-8). The statute also made provision for sanctions and remedial interventions for offenders, including punitive disciplinary measures as well as educational and supervisory requirements. ${ }^{1}$

The Legal Profession Act 2004 followed the 1996 Act and was based on a model national law enacted to varying degrees across Australia's states and territories. This legislation deregulated the structure of law firms and allowed the establishment of incorporated legal practices, which do not restrict who may own shares in the entity. The legislation has been controversial, largely owing to concerns that external investment and commercial pressure may adversely affect professionalism and dilute individual responsibility for providing competent legal services (Parker 2004). To guard against such potential ethical risks, incorporated legal practices are required to implement and maintain 'appropriate management systems' which are subject to higher level of regulatory oversight than traditional law firms (Parker et al. 2010). ${ }^{2}$ Lawyers in Victoria apply for an annual practicing certificate from LSBC each year if they are engaged in legal practice, and are subject to regulatory oversight by the LSBC.

\section{B. The Complaints Process}

The LSBC consists of two entities: The Legal Services Commissioner ('the Commissioner'), who receives and handles complaints about lawyers, and the Legal Services Board ('the Board'), which is responsible for all other regulatory functions. The two entities share a chief executive and staff (Box 1). The Commissioner is the primary external avenue of redress for

\footnotetext{
1 The regime has been modified several times since 1996. The most recent revision, the Legal Profession Uniform Law Application Act 2014, commenced in Victoria in 2015, at the end of our study period.

${ }^{2}$ Section 2.7.10(3) requires legal practitioner directors to ensure that appropriate management systems are implemented and maintained. Appropriate management systems are subject to audit checks and compliance reporting requirements. Checks may include whether the legal practice has policies and procedures in place for conflict of interest identification and resolution, records management and supervision of practice and staff.
} 
individuals who are dissatisfied with legal services or have concerns regarding a lawyer's professional conduct.

Lawyers and clients are encouraged to resolve matters between themselves where possible. Advice provided by the Commissioner in response to an initial enquiry will often be sufficient to avert the filing of a formal complaint. Any person or body may lodge a complaint about a lawyer and, in some circumstances, the Commissioner may initiate a complaint. In practice, most complaints are lodged by dissatisfied clients. As discussed in our limitations section, the fact that a complaint was lodged does not mean that misconduct occurred, nor does the absence of a complaint mean that services were of an appropriate standard. Complaints tend to reflect the types of concerns that have the most salience to clients.

Most complaints, particularly those that relate to cost disputes, are resolved by the Commissioner without a requirement for a formal disciplinary hearing. The most serious complaints result in disciplinary charges before a tribunal, which may lead to a lawyer having their license to practice restricted or suspended. The LSBC maintains detailed records of complaints received, the issues raised and their outcomes, and an up-to-date register of all lawyers in the state, including demographic data and place of work.

\section{Risk Factors for Complaints and Disciplinary Action in the Legal Profession}

The few empirical studies of complaints against lawyers that have been conducted to date have identified male sex (Bartlett 2008; Hatamyar \& Simmons 2004; Curtis \& Kaufman 2004), older age, (Davies 1999; Hatamyar \& Simmons 2004), and solo practice as risk factors for complaints and disciplinary actions (Brook 1997; Arnold \& Hagan 1992; Levin et al. 2013).

Hatamyar and Simmons conducted a cross-sectional study of publicly-reported disciplinary actions imposed against lawyers in the US in 2000 (Hatamyar \& Simmons 2004). The researchers struggled with substantial variation in the quality and availability of data 
across the 50 states, but managed to obtain and analyze 3,461 cases. ${ }^{3}$ The study showed that female lawyers were disciplined at a significantly lower rate than their male colleagues: while $24 \%$ of the lawyers in US at the time of their study were female, nearly $90 \%(3,461 / 3,055)$ of disciplinary actions were against male lawyers. However, conditional on disciplinary action being taken, sex was not significantly associated with length of suspensions imposed. Similarly, examining disciplinary reports over a 15-year period from the Florida Bar, the licensing agency for practicing lawyers in that state, Curtis and Kaufman found a wide gap in the proportion of disciplinary actions involving male and female lawyers, with an average of 90\% involving male lawyers (Curtis \& Kaufman 2004).

Previous research also suggests that lawyers in older age groups have higher rates of some forms of disciplinary action than their younger colleagues. In a United Kingdom (UK) study, Davies analyzed 270 randomly-selected orders issued by the Solicitors Disciplinary Tribunal between 1994 and 1996; the sample represented 49\% of all orders issued in the period (Davies 1999). The study focused on dishonest conduct, which the Tribunal identified explicitly or implicitly in 37\% of the cases analyzed, and found that older lawyers were overrepresented among offenders. ${ }^{4}$ Hatamyar and Simmons also found that disciplined lawyers in the US were on average older than lawyers generally (Hatamyar \& Simmons 2004). Their study found the median age of disciplined lawyers in 2000 was 50 for males and 46 for females; whereas, the median age for American lawyers in the same year was 45 (Carson 2004).

\footnotetext{
${ }^{3}$ The researchers were able to access some of their data through the American Bar Association's Center for Professional Responsibility, which periodically publishes survey data on information received from the disciplinary agencies across the US and also maintains the National Lawyer Regulatory Data Bank. The information provided by the states to the Center for Professional Responsibility is voluntary and the content varies by state.

${ }^{4}$ Davies did not provide the overall age distribution for all practicing solicitors in the UK from 1994 to 1996 when he conducted his study. However, he included 'years qualified to practice' in his study and he grouped his sample into three categories: $24 \%$ had been qualified for under 10 years, $47 \%$ for between 10 and 20 years and $29 \%$ for over 20 years. He found when looking at the legal profession as a whole solicitors qualified for between 10 and 20 years were over-represented for disciplinary action related to dishonest conduct as they accounted for $35 \%$ of all practicing solicitors in the UK during his study period.
} 
Another study from the UK and two studies from North America identified solo practice as a risk factor for complaints and disciplinary action (Brooke 1997; Arnold \& Hagan 1992; Levin et al. 2013). In the UK, Brooke found that solicitors in solo practice were more likely to experience serious professional problems related to alcohol abuse than their peers working in other types of practices (Brooke 1997). Arnold and Hagan's analysis of prosecutions for professional misconduct in an unspecified Canadian province between 1979 and 1986 found that inexperienced lawyers and lawyers in solo practice had the highest rates of prosecution for complaints of misconduct (Arnold \& Hagan 1992). However, part of this elevated risk may have been attributable to selective monitoring and enforcementspecifically, decisions by regulatory agencies to target inexperienced lawyers and solo practitioners for surveillance and sanctioning.

In a series of studies Levin found that solo practitioners are more likey to receive complaints and be disiciplined. (Levin 1998; Levin 2004; Levin 2012; Levin et al. 2013; Levin 2016). Similarly an American Bar Association analysis of legal malpractice claims in 2011-15 found that firms of five or fewer lawyers accounted for a disproportionately large share of them (MacGregor \& Vail 2016). Possible explanations for this increased risk include lack of supverision from senior partners, individual or small business clients who may be more likely to initate complaints than corporate clients, increased scrutiny of solo practitioners by regulators, and limited resources to handle disputes brought against them.

In sum, the existing body of quantitative research examining risk factors for complaints and disciplinary action against legal practitioners is small but provocative.

\section{Risk Factors for Medical-Legal Events}

In contrast, over the last 30 years, dozens of empirical studies had investigated patterns of and risk factors for malpractice claims and unsolicited patient complaints against health care professionals. This research has shown that readily identifiable characteristics of doctorsincluding specialty, age, sex, communication skills, and medico-legal and medical school history_are associated with elevated risks of both types of events (Sloan et al. 1989; Taragin 
et al. 1992; Levinson et al. 1997; Morrison \& Wickersham 1998; Hickson et al. 2002; Kohatsu et al. 2004; Papadakis et al. 2005; Jena et al. 2011; Bismark et al. 2013).

More recent research has homed in on track records, and demonstrated that complaints and claims are highly maldistributed, clustering among a relatively small group of doctors (Tibble et al. 2017; Studdert et al. 2016; Spittal et al. 2015; Bismark et al. 2011; Jena et al. 2011; Rolph et al. 2007). For example, in a national sample of nearly 19,000 complaints about doctors lodged with Australian health complaints entities over an 11-year period, 3\% of the medical workforce accounted for $49 \%$ of all complaints (Bismark et al. 2013). Similarly, a study of over 66,000 paid malpractice claims in the US found that approximately $1 \%$ of all practicing doctors accounted for 32\% of paid claims (Studdert et al. 2016).

With many risk factors now relatively well established, the leading edge of this line of research has shifted toward development of tools that permit reliable, individual-level prediction of doctors at highest risk of entering "frequent flyer" enclaves. The goal is to arm regulators with predictive tools that can help avert future harm by alerting regulators to high risk practitioners before they accumulate troubling track records (Spittal et al. 2015).

\section{METHODS}

\section{A. Data}

Our sample consisted of all disciplinary complaints lodged with LSBC regarding lawyers registered to practice in Victoria between 1 July 2005 and 30 June 2015. Study data were collected onsite at the LSBC offices in Melbourne between February 2016 and June 2016.

Our analytic dataset was formed by combining two de-identified datasets: one consisted of lawyer-level information on all lawyers registered to practice in Victoria during the study period ("lawyer dataset”) and the other consisted of all complaints and misconduct findings made in relation to those lawyers during the study period (“complaint dataset”).

We collated the lawyer dataset from information submitted by lawyers in new and annual renewal applications for practicing certificates. The information we obtained included 
a unique code identifying each registered lawyer (common across years for the same practitioner); the sex and date of birth of each lawyer; a variable indicating whether the lawyer had authority to operate a trust account; and the location, structure and size of the lawyer's practice. The data were longitudinal in nature, allowing specification of timevarying variables (e.g. practice location).

To be permitted to manage client funds held in trust by a practice, lawyers must first apply for and receive trust account authority from the LSBC (Legal Profession Uniform General Rules 2015, ss. 33 to 60$).{ }^{5}$ This authority gives rise to additional fiduciary responsibilities for the recipient lawyer and the potential for disciplinary charges if the rules are not strictly followed. The LSBC closely monitors the conferral of trust account authority. We obtained variables indicating which lawyers in the study dataset held such authority, and in what years.

The complaints dataset included fields indicating the area of law to which each complaint related, the date the LSBC received the complaint, the types of concerns raised in the complaint, and complaint outcomes. The complaints dataset also included a variable identifying the lawyer to whom the complaint related by means of the same unique practitioner code as appeared in the lawyer dataset.

We combined the lawyer and complaint datasets using the unique lawyer identifier to create a person-period analytical dataset. Each row in this dataset represented a year of practice by a particular practitioner. Complaints variables were recorded in the year in which the complaint occurred. Thus, a lawyer registered to practice in every year of our study period who had a complaint in 2009 would have had ten rows of data and an indication of complaint (plus associated complaint-level variables) in the row pertaining to 2009.

\footnotetext{
5 The current legislation in Victoria overseeing the operation of trust accounts is under the Legal Profession Uniform General Rules 2015, which includes specific requirements for lawyers holding trust account authority and the keeping of trust records.
} 
We excluded lawyers who were younger than 26 years or older than 65 years, barristers, ${ }^{6}$ and lawyers who practiced interstate or overseas. The age restrictions were imposed because as lawyers under the age of 26 years are often still in supervised legal practice, which means the nature of their work and complaint risk may differ from lawyers who are not subject to supervision. Lawyers over the age of 65 were excluded because they, on average, work fewer hours than their younger colleagues, thus reducing their work timerelated exposure to complaint risk and creating a possible confounder in our analyses. ${ }^{7}$ Barristers were excluded because they cannot be instructed directly by clients, ${ }^{8}$ making their profile of complaints not directly comparable to solicitors. We also excluded lawyers who were admitted to the legal profession but did not hold an annual practicing certificate because this indicated they were not engaged in (lawful) legal practice in Victoria during the study period.

\section{B. Variables}

We coded lawyers into ten-year age bands and allowed them to move bands during the study period, according to their age in each year. We classified lawyers' primary practice location as urban or non-urban using a standard geographical classification system (Australian Bureau of Statistics, 2015). Under this classification system, major urban areas are defined as those areas with a population of 100,000 people or more, and urban areas are defined as having a

\footnotetext{
${ }^{6}$ In Victoria, similar to other jurisdictions in Australia, the law profession includes both barristers and solicitors. A barrister, also known as an independent advocate, specializes in representing clients in court. An Australian lawyer who wishes to practice as a barrister generally does so by undertaking the Bar Readers' Course and serving as an apprentice to another barrister for a period of nine months. Barristers in Victoria are members of the Victorian Bar where they are governed by a different set of rules than solicitors, including the Uniform Conduct (Barristers) Rules, the Uniform Continuing Professional Development (Barristers) and they exclusively practice as a barrister. Solicitors, by contrast, may instruct barristers and represent clients in some courts.

${ }^{7}$ We did not have access to working hour data for the lawyers in our study, and were therefore unable to control for worktime-related exposure in our analyses. Previous research with doctors has shown that controlling for working hours reveals increased complaint risk among older practitioners (Tibble et al. 2017).
}

\footnotetext{
${ }^{8}$ Each barrister practices alone as an individual and is not permitted to practice in partnership or as an employee,
} and is not permitted to practice as the employer of any legal practitioner in active practice. 
population between 1,000 and 99,999. ${ }^{9}$ In Victoria, three-quarters of the state's population (around 4.5 million people) are categorized as living in major urban areas or urban areas. All other areas were defined as non-urban or rural areas and comprise the remaining quarter of the state’s population (nearly 1.5 million people).

Type of legal practice was grouped into four categories, based on a classification system used by the LSBC: incorporated legal practice, traditional law firm (solo practitioners ${ }^{10}$ and law firms), in-house counsel (non-legal or government employers and multidisciplinary partnerships), and community legal center. Lawyers may record more than one type of legal practice on their practicing certificate renewal; our variable used the one designated as their primary type.

The size of practice variable was based on the number of registered lawyers working within the same organization. For lawyers working in-house at a government or corporate organization, this variable indicates the number of registered lawyers in the organization. We collapsed these organization-level lawyer counts into three categories: small (1-10 lawyers); medium (11-100 lawyers); and large (>100 lawyers). We chose 1 to 10 lawyers as our smallest category because the estimates were unstable with group-size specifications smaller than this.

As shown and further defined in Box 2, we coded the issues raised in complaints into eight types based on a taxonomy developed and used by the LSBC. The categories were: communication, competence and diligence, compliance, costs, ethical matters, personal conduct, trust accounts, and other. In addition, as part of routine case handling, the LSBC case-managers coded the primary area of law to which each complaint issue related into the following categories: family, property, wills and estates, personal injury, commercial, criminal, debt collection, and other. Our analysis used the same categories.

\footnotetext{
${ }^{9}$ The Australian Statistical Geographical Standard (ASGS) definitions for urban and rural areas: http://www.abs.gov.au/websitedbs/D3310114.nsf/home/Frequently+Asked+Questions\#Anchor7, last accessed on September 10, 2017.

${ }^{10}$ Solo practitioners are lawyers who are the sole principal of a law firm, but they may employ other lawyers.
} 


\section{Analysis}

We used counts and proportions to describe characteristics of lawyers who were the subject of complaints, the legal workforce in Victoria over the study period, and the characteristics of complaints. We then conducted multivariate logistic regression analysis at the lawyer-year level to identify predictors of complaints.

The primary outcome in the regression analysis was the occurrence of a complaint. Specifically, the outcome variable had a value of ' 1 ' for each year in which a registered lawyer experienced one or more complaints and a value of ' 0 ' for each year in which a registered lawyer experienced no complaints. A secondary subanalysis was restricted to the subset of complaints that resulted in a misconduct finding; this outcome variable was specified in the same way. The covariates in both regression models were the lawyer's sex; the lawyer's age and trust account authority status in the relevant year; and the location, type and size of the lawyer's practice in the relevant year.

Because our analytical dataset consisted of multiple observations over time for most lawyers, we fit this model using methods appropriate for panel data. Specifically, we used a generalized estimating equation for binary outcomes with a binary family and log link. This method accounts for within-lawyer covariance as well as the between-lawyer differences, and is a standard method in epidemiological research for repeated binary data.

We conducted all analyses using Stata statistical software (Stata Statistical Software: Release 14, College Station, TX).

\section{Ethics Review}

The University of Melbourne's Human Ethics Sub-Committee approved the study. The LSBC provided de-identified data under a strict data protection plan and deed of confidentiality. 


\section{Results}

The analytical sample consisted of 20,090 lawyers aged between 26 and 65 years who were registered to practice law in Victoria between July 2005 and June 2015. Over this period the LSBC received 15,887 complaints against 4,180 of these lawyers, an average of 3.8 complaints per lawyer among lawyers with one or more complaints. Many of the complaints involved multiple issues, with a total of 21,938 separate issues among the 15,887 total complaints.

\section{A. Characteristics of Lawyers and Lawyers Subject to Complaints}

Table 1 shows the characteristics of all registered lawyers in Victoria (column 2) and the subset of them who were subject to complaints (column 3) as at the beginning of the study period in 2005.

Female lawyers comprised half of the legal workforce (50\%). Most lawyers practiced in urban areas (93\%). Seventeen percent of lawyers had trust account authority. Over half of practicing lawyers (56\%) worked in traditional law firms, 16\% were in incorporated legal practices, and $22 \%$ were employed as in-house counsel. Nearly half of the lawyers (48\%) were based in small firms and one-quarter in large firms.

Among lawyers subject to complaints during the study period, lawyers practicing in nonurban areas accounted for $13 \%$ of all complaints. Over two-thirds of complaints (69\%) involved male lawyers. Nearly half of the complaints (47\%) involved lawyers with trust account authority. Most complaints involved lawyers practicing in traditional law firms (72\%) and over a fifth of lawyers (22\%) with complaints worked in an incorporated legal practice. Nearly three-quarters of complaints (72\%) involved lawyers working in small firms, with only $6 \%$ involving lawyers from large firms.

1. Characteristics of Complaints 
Clients or members of the public lodged 91\% of complaints and 7\% were lodged by lawyers' peers. The LSBC itself was the source of only $2 \%$ of complaints.

Three complaint issues featured in $79 \%$ of all complaints (Table 2): the cost of legal services (36\%), competence and diligence (22\%), and ethical matters (21\%). Complaint issues regarding communication (10\%) and trust accounts (8\%) comprised an additional 18\% of all complaints. Complaints over compliance matters (3\%) and personal conduct regarding a lawyer's character or behavior unrelated to a particular case $(0.2 \%)$ were relatively rare. More than half of all complaint issues pertained to three areas of law: family law (24\%), property (19\%), and wills and estates (13\%).

Almost all issues raised in complaints were resolved by the end of the study period $(21,859 / 21,938)$. Three quarters of the closed complaint issues were dismissed by the LSBC, $17 \%$ had a resolution with no misconduct finding and 7\% resulted in a misconduct finding. ${ }^{11}$

Five percent of the complaints lodged by clients or members of the public resulted in a misconduct outcome and 7\% of 7\% of complaints lodged by peers did. Though only 1 in 50 complaints were initiated by a regulatory agency, $50 \%$ of them resulted in a misconduct outcome (data not shown).

\section{Risk Factors for Complaints}

All six of the lawyer characteristics we examined in the multivariable regression analysis were associated with lawyers' odds of being subject to at least one complaint (Table 3). Compared with female lawyers, male lawyers had 49\% higher odds of being named in one or more complaints (OR=1.49, 95\% CI: 1.37 to 1.62). The odds of experiencing complaints among lawyers with trust account authority were 2.9 times higher, compared to lawyers without this authority (OR=2.90, 95\% CI: 2.69 to 3.13). Lawyers located outside the urban areas of Victoria had $27 \%$ higher odds of being subject to a complaint, compared with lawyers in urban areas (OR=1.27, 95\% CI: 1.15 to 1.41). Compared with lawyers aged 26 to

\footnotetext{
${ }^{11}$ Resolved complaints include those that were dismissed or resolved.
} 
35 years, lawyers aged between 56 and 65 years had 1.56 times the odds of experiencing complaints (OR=1.56, 95\% CI: 1.41 to 1.73 ). Compared with lawyers working in traditional law firms, in-house lawyers (OR=0.20, 95\% CI: 0.17 to 0.23 ) and lawyers working in community legal centres (OR=0.58, $95 \% \mathrm{CI}$ : 0.49 to 0.70$)$ had substantially lower odds of experiencing complaints, while lawyers employed in incorporated legal practices had 37\% higher odds (OR=1.37, 95\% CI: 1.27 to 1.47). Lawyers in small firms had more than three times higher odds of complaints than lawyers in large firms (OR=3.37, 95\% CI: 3.01 to 3.78) and lawyers in medium-size firms had more than twice the odds (OR=2.55, 95\% CI: 2.26 to 2.88).

Re-running the multivariable model after restricting the outcome to complaints resulting in misconduct findings showed similar results (Table 3). Only practice location ceased to be a significant predictor. The strength of the association increased for most of the rest of the predictors, especially small firm size (OR=13.4, 95\% CI: 7.71 to 23.2).

\section{Discussion}

This study adopted an epidemiological approach to the study of lawyers who are subject to complaints and misconduct findings, in order to improve understanding of their characteristics. To the best of our knowledge, no previous studies of disciplinary risks have calibrated estimates against the full legal workforce of a jurisdiction, and none have explored such a comprehensive a set of descriptors.

Results aside, the study's analytical approach study suggests a useful way for regulators of the legal profession to more fully use and learn from data they routinely collect. In this Section, we discuss the study's contribution to advancing the empirical evidence on lawyer misconduct and disciplinary action. We also consider strengths and limitations of our analytical approach.

\section{A. Nature of Complaints and Complaint Outcomes}


Complaints can illuminate common 'on the ground' concerns about professionals, and can provide valuable insights into breaches of professional standards, as well as public and client expectations (Parker et al. 2010; Haller 2010). In our study, the three leading grounds for complaint were-in descending order of prevalence--costs, competence and diligence, and professional ethics.

Over a third of the complaints raised concerns about the cost of legal services. Unlike medical services, Australia has no universal system of insurance for legal services. Limited access to civil legal aid, coupled with the prohibition on contingent fees, mean that most legal services must be paid for out-of-pocket. These factors may help to explain why costs are such a common flashpoint in lawyer-client relations (Semple 2013). At the end of our study period, new legislative rules were introduced requiring lawyers to provide clients at an early stage with a quote a specific price for the services sought, as opposed to a price range, which had been permitted under prior rules. ${ }^{12}$ To the extent that surprise bills and unmanaged expectations drive conflict, this reform may be salutary.

The second and third most common issues raised in complaints involved concerns about competence and diligence and ethical matters. Many competence and diligence complaints centered on concerns about poor advice and case handling, whereas complaints over ethical matters covered a heterogeneous array of concerns ranging from breaches of confidentiality to failures to comply with court orders (see complaint sub-issues listed in Box 2). Similar types of unprofessional conduct have been identified as priority areas by the American Bar Association’s Center for Professional Responsibility. ${ }^{13}$

\footnotetext{
${ }^{12}$ Cost disclosure obligations where lawyers are required to provide a range for estimated legal costs were introduced in the Legal Practice Act 1996. The right for a client to request an itemized bill was introduced in the 1996 Act (section 108) and preserved in subsequent legislation Legal Profession Act 2004 (section 3.4.36). The current governing legislation has this provision in Legal Profession Uniform Law Application Act 2014 (section 187). In addition, the 2014 Act requires lawyers to provide an estimate for legal costs (section 174).

${ }^{13}$ This American Bar Association Center for Professional Responsibility regularly produces continuing legal education information for lawyers to identify common situations that lead to professional misconduct and recommends strategies to avoid them. http://www.abajournal.com/magazine/article/top_10_ethics traps, last accessed June 19, 2017.
} 
Although fellow practitioners are often well-placed to observe and assess misconduct among their peers, fewer than $10 \%$ of the complaints in our sample were lodged by them. This finding raises questions about barriers to lawyers speaking up about poor performance within the profession. Within the medical profession, similar concerns have been raised about a "club culture" which deters doctors from calling out risks to the public (Kennedy et al. 2000). In Australia, mandatory reporting laws now require all registered health practitioners to notify the regulator if a fellow practitioner has practiced while intoxicated, engaged in sexual misconduct, or placed patients at substantial risk of harm because of a health impairment or significant departure from professional standards (Bismark et al. 2014). Such duties have not yet been imposed on the legal profession. Indeed, the Conduct Rules for the legal profession warn lawyers against making allegations of professional misconduct without reasonable grounds and supporting material, with no corresponding duty to speak up when a lawyer believes that a colleague's conduct is placing the public at risk of harm. ${ }^{14}$

The finding that fewer than $7 \%$ of all complaints resulted in a misconduct finding resonates with studies of doctors that have shown most complaints do not lead to adverse findings, regulatory action or payments (Spittal 2016; Mello et al. 2010). In the United States, legal malpractice claims that result in favorable verdicts for the plaintiffs are rare. Around $2.5 \%$ of legal malpractice claims reach a trial verdict, and only about a third of those find for the plaintiff (Kritzer \& Vidmar 2015). Though it may be tempting to infer from these findings that unfounded complaints are common, such a conclusion is unwarranted. Complainants may have sincere concerns, which are only alleviated by the discovery of additional information through the complaint investigation process. Alternatively, regulators may face evidentiary difficulties in investigating and adjudicating certain forms of professional misconduct. It can be difficult to determine error from filings and orders in litigation, because what seems like an error to one lawyer may be a smart tactical decision to another.

Our findings also raise questions about the perspectives, motivations, and knowledge of those who lodge complaints. Early evidence suggests that vulnerable groups, such as

\footnotetext{
14 Legal Profession Uniform Law Australian Solicitors' Conduct Rules 2015 under the Legal Profession
} Uniform Law. https://www.legislation.nsw.gov.au/regulations/2015-244.pdf, last accessed January 25, 2018. 
elderly, socioeconomically deprived, or those with an ethnic minority background may be less likely to participate in the regulatory process and file a complaint (Bismark et al. 2011; Carney et al. 2016). Further investigation focused on individuals who received substandard services, but did not lodge a complaint, may help to illuminate biases and barriers in the types of misconduct that are brought to the attention of regulators. Analogous studies in the medical-legal realm have been illuminating. (Burstin et al. 1993; Studdert et al. 2000; Bismark et al. 2006)

\section{B. Factors Associated with Higher Risk of Complaint \\ 1. Male Sex}

Compared with their female peers, male lawyers had higher odds of both experiencing a complaint and being subject to a misconduct finding. The overrepresentation of males among disciplined lawyers is consistent with previous empirical studies of lawyer misconduct (Hatamyar \& Simmons 2004; Curtis \& Kaufman 2004). An important limitation of this finding is that we were unable to account for differences in hours worked by male and female lawyers. An estimate from another state in Australia, New South Wales, found that the proportion of female solicitors in part-time employment was twice that of male solicitors (21\% vs 10\%) (Law Society of New South Wales 2013). This is relevant as lawyers who work part-time are likely to have fewer client encounters, which may partly explain their lower rate of complaints. Studies of doctors suggest that adjusting for hours worked reduces, but does not eliminate, the higher complaint rate among male practitioners (Unwin et al. 2014; Tibble et al. 2017).

The doctor studies also show that male sex persists as a risk factor for complaints, malpractice claims and disciplinary actions after adjusting for other confounders, including age and specialty. Why? Levinson and colleagues have identified a positive association between the quality of patient- doctor communication and medico-legal risk. This research has also found systematic differences in communication style and quality by gender: female doctors are more likely to adopt a democratic style of communication in which they engage 
patients in decision making about their care and provide more emotional support (Levinson \& Lurie 2004). A similar explanation may lie behind the increased risk of complaints among male lawyers.

Over the study period, there was a steady increase in the proportion of female lawyers, although women continue to be significantly underrepresented at the highest levels of the profession. Increases in the number of female law students and lawyers are also evident elsewhere in Australia and internationally. (Law Society of New South Wales 2014; American Bar Association 2016). If the risk difference is real between male and female lawyers, and not explained by analytical artefacts such as exposure time or selective enforcement, then feminization of the legal workforce should continue to exert downward pressure on the number and incidence-and likely also patterns--of misconduct complaints.

\section{Older Age}

We found that lawyers in the older age groups were at increased risk of complaints, including complaints with misconduct outcomes. This finding is broadly consistent with previous research in both the legal and medical professions (Unwin et al. 2014; Spittal et al. 2016; Hatamyar \& Simmons 2004; Tibble et al. 2017). There are several plausible explanations for the seemingly counterintuitive finding that more experienced lawyers are at higher risk of complaint and misconduct findings. Younger lawyers tend to be more closely supervised and are less likely to be making major decisions on their own, while older lawyers may work in roles with higher levels of responsibility and accountability. For example, more senior lawyers may be targeted in their capacity as a figurehead, especially in relation to concerns such as billing that implicate organization-wide policies and practices.

Differences in the nature of the work at hand aside, older age remains plausible a risk factor. Skills eventually atrophy. Older lawyers may develop habits and set ways of operating that are (or become) out of step with professional standards; they may also become less vigilant as confidence in their own skills and knowledge grows. Additionally, some scholars have suggested that the risk of addiction and health issues may increase with age and, in turn, 
these factors may lead to higher risks of complaints and misconduct findings (Hatamyar \& Simmons 2004; Davies 1999).

\section{Trust Account Authority}

Lawyers who held trust account authority had nearly three times the odds of experiencing complaints than those who did not have this authority. This is a clear "hot spot" of risk, and highlights on possible target for continuing legal education. Although the issue codes we used were informative, they were not granular enough to determine the extent to which the risk was driven by complaints related directly to misuse of trust monies.

Visibility of potential misconduct may also play a role here. Legal regulators in Victoria and other states in Australia view the oversight of trust accounts as one of their primary functions and impose heavy compliance and reporting requirements in this area (Briton 2015; Parker et al. 2010). Thus, the finding that trust account authority is a risk factor for complaints may - at least in part - reflect the intensity of oversight rather than a higher incidence of troubling behavior of this subgroup.

\section{Non-Urban Practice}

Lawyers who practiced in non-urban areas had higher risk of complaints, but not of complaints ending in misconduct findings. Several factors may be relevant in explaining this result, including client income and limited service availability.

Like most industrialized countries, incomes are lower in non-urban areas of Australia than in urban areas (Australian Bureau of Statistics 2011). In addition, non-urban areas have fewer lawyers per capita than urban areas (Law and Justice Foundation of New South Wales 2014), and some non-urban law firms in Australia report difficulty in attracting high quality lawyers due to the lower salaries, professional isolation, and other challenges of regional and rural practice (Mundy et al. 2017). These supply constraints may cause clients frustration at 
the outset and compromise their ability to access high quality legal services, an unhappy mix that may enhance risks of client dissatisfaction.

Concerns about the availability and quality of legal services outside cities are longstanding. Ongoing efforts to address the problem, such as the Rural, Regional and Remote (RRRLaw) initiative, have potential. ${ }^{15}$ Metrics such as client satisfaction levels and complaint rates warrant inclusion in any evaluations of their success

\section{Incorporated Legal Practice}

Of all types of types practice examined, lawyers working in incorporated legal practices were the most likely to experience complaints, even after adjusting for practice size.

The opportunity for firms to incorporate arose a year before the start of our study period with a legislative change in the Legal Profession Act 2004 that allowed incorporated legal practices to operate nationally (Grech \& Morrison 2007). Over the study period, the proportion of lawyers working for incorporated legal practices in Victoria more than doubled from $7.5 \%$ in 2005 to $18.4 \%$ in 2015.

Theory provides a ready explanation for the elevated rise of complaints for practitioners in these firms: moral hazard. Directors of incorporated firms have less exposure to personal liability for their actions than do partners in traditional law partnerships, where joint and several liability applies. The protections may contribute to lawyers behaving in ways that are contrary to the best interests of their clients-a risk of allowing incorporation that commentators identified early on (Parker 2004). Our finding, coupled with the rapid growth for this type of legal practice, points to an important area for additional research.

\section{Small Practice}

\footnotetext{
15 The Law Council of Australia leads the RRRLaw initiative for the Australian Government in response to a 2009 national study that found the difficulty attracting lawyers to practice in non-urban areas is having a negative impact on the people living in these communities when it comes to accessing legal services. The RRRLaw initative provides incentives for recruitment as well as mentoring and professional support to promote retention. http://rrrlaw.com.au/what-is-rrr-law/rrr-initiative/, accessed on January 25, 2018.
} 
We found a negative association between practice size and complaint risk, with the odds of complaint decreasing with the number of fellow lawyers. Compared with lawyers in large legal practices, lawyers in small practices had more than three times the odds of experiencing a complaint and 13 times the odds of a misconduct finding - by far the largest effect size of any in our results. These findings are consistent with previous studies that found elevated risks among lawyers in solo practice and small firms (Arnold \& Hagan 1992; Brook 1997; Levin et al. 2013).

There are many possible explanations for increased risk among lawyers working in small practices. First, some of the risk may be linked to differences in the mix of clients and work across firm sizes, with a greater share of smaller practices' work dealing with individual clients in one-off matters. By contrast, a greater share of larger practices' work involves corporate clients with whom the firm has ongoing, sometimes longstanding, professional ties - a relationship less likely to provoke disputes. Second, a larger share of work in smaller firms may be in areas (e.g. family law, wills and estates) that are especially vulnerable to client-lawyer disputes. Levin has referred to such practice areas zones of 'personal plight' areas, where disputes are emotionally charged, and clients are often vulnerable (Levin et al. 2013).

Third, lawyers in smaller practices tend to undertake a broader range of work and have less specialist expertise. Fourth, opportunities to stay abreast of relevant changes in the field are more plentiful within law firms, peers may act as a check on improper behavior, and team-based service may diffuse tensions that arise in one-on-one client relationships. Recognizing the distinctive challenges that solo and small practices face, the American Bar Association has established a dedicated resource center designed to support them. ${ }^{16}$

Fifth, larger firms have a range of other resources available to them to avert or manage client dissatisfaction. For example, some large firms have risk-management guidelines and procedures imposed on them by liability insurers. Many also have established management

\footnotetext{
${ }^{16}$ https://www.americanbar.org/portals/solo_home/solo_home.html, last accessed September 10, 2017.
} 
practices for quelling or resolving looming grievances, thereby averting regulator involvement (Levin 2004). Such resources are unusual in smaller firms.

Finally, biases in the intensity of regulatory oversight cannot be discounted as an explanation for the higher complaint risk among practitioners in small firms. Other researchers have suggested that regulators may focus disproportionately on them (Arnold \& Hagan 1992; John 2014; Levin 2004). It was beyond the scope of this research to disentangle the force of these various explanations, but future research should.

\section{Study Strengths and Limitations}

Our study has two key strengths relative to existing work in this area: the scope of data collected and the sophistication of our analytic methods. As previously noted, data on lawyer discipline is fragmented and often not readily available. Curtis and Kaufman note the "Herculean effort” involved in conducting research on lawyer misconduct in the US (Curtis \& Kaufman 2004). Our study benefited from direct access to administrative data held by the LSBC and strong support from the regulator for the research.

Previous research into complaints and misconduct involving lawyers has relied largely on simple counts and percentages. Our use of adjusted analyses improved our ability to reduce risks of confounding and isolate the effect of certain firm and lawyer characteristics. For example, previous studies have suggested that over-representation of male lawyers in professional misconduct cases might be explained by the fact that older lawyers are more likely to be male and that age is a risk factor (Curtis \& Kaufman 2004). We show that male sex remains a risk factor, even after controlling for age, practice location, and size and type of law firm.

Notwithstanding the access to comprehensive data we enjoyed, we still encountered substantial challenges in establishing a clean and comprehensive dataset suitable for statistical analysis. Like most other regulators, the LSBC collects data for administrative rather than research purposes. For example, the LSBC process for renewal of annual practicing certificates does not collect information about hours worked or area of law for 
lawyers registered in Victoria. At least some of the difference in complaint risk between male and female lawyers is likely to be explained by men working longer hours, on average, and thus having greater exposure the risk of complaints. Further background information, such as law school attended and country of training, may also have improved the precision of our estimates, and extended understanding of plausible risk factors. As is common when administrative datasets are deployed to research uses, we encountered missing and incorrect fields, inconsistent spelling of names for the same lawyer across years, use of multiple unique identifiers for the same lawyer, and missing data. A considerable amount of cleaning and recoding was required to prepare the data for analysis.

A broader limitation of our study stems from the data type: disciplinary complaints are an imperfect marker of quality. For one, they almost certainly represent the tip of the iceberg of substandard legal practice. For every consumer of legal services who lodges a complaint, there are undoubtedly many more who are aggrieved but do not act. Moreover, the complaints received by the Commissioner are likely to be skewed towards issues, such as cost and delays, that are visible to clients, rather than more technical errors such as a lawyer failing to ask a particular question at a deposition. Other reasons for not filing a complaint may include: lack of knowledge of complaint mechanisms; fear of repercussions; lack of confidence in the legal regulatory system; a preference for other means of resolving the dispute such as litigation; unwillingness to expend the time and effort required; or belonging to a vulnerable group that is less likely to participate in the regulatory process (Briton 2015; Carney et al. 2016; Bismark et al. 2011).

While the "under-complaining" described above is likely to be the most important source of imprecision in attempts to use complaints to legal regulators as a window on incidents of substandard legal practice, “over-complaining” also warrants mention. Laypeople typically struggle to know whether a lawyer did a poor or good job negotiating a contract or litigating a case. Some complainants are motivated by a misunderstanding of lawyers' obligations, distress over losing a case, or personal rivalry. The high degree of consistency between our estimates from the model analyzing all complaints and the model 
analyzing complaints that resulted in misconduct findings is reassuring, and suggests that the presence of unfounded complaints does not materially affect the risk factors we identified.

Finally, similarities between the LSBC model and regulatory regimes governing the legal profession in other Australian states and jurisdictions abroad suggest that our methods and findings have relevance elsewhere, but generalizability beyond Victoria is unknown.

\section{CONCLUSION}

Regulators of the legal profession are charged with protecting the public by ensuring lawyers are fit to practice law. However, their approach tends to be reactive and case-based, focusing on the resolution of individual complaints. Regulators generally do not seek to identify patterns and trends across their broader caseloads and the legal profession as a whole. A more modern approach to regulation calls for regulators to make effective use of the administrative data they hold, to identify priority areas for intervention and to better allocate scarce resources to reduce the risk of future harms (Bismark et al. 2015; Sparrow 2000).

Using data routinely collected by the main regulator of the legal profession in Victoria, Australia, we analyzed risk factors for complaints and misconduct findings. We emulated an analytic approach that has been used to study risk among doctors, and adapted it for the legal profession. We identified six risk factors associated with complaints among lawyers in Victoria: male sex, older age, holding trust account authority, and working in a legal practice that is smaller, in a non-urban location, or incorporated. Similar patterns are likely to exist in other jurisdictions in Australia and internationally.

For most regulators of the learned professions, peering past the "trees" of individual cases into "forest" of caseloads is an intimidating prospect, and one that would constitute a radical break from established modes of doing business. Our findings suggest that for legal regulators, it is feasible, worthwhile, and arguably essential to effectively pursuing their dual mission of upholding professional standards and protecting the public from substandard legal services. 


\section{REFERENCES}

Abel, R. (2008) Lawyers in the dock: Learning from attorney disciplinary proceedings, New York, Oxford University Press.

Abel, R. (2012) “Comparative studies of lawyer deviance and discipline,” Legal Ethics, 15, 187-195.

Akiskal, K. K., M. Savino, \& H. S. Akiskal (2005) "Temperament profiles in doctors, lawyers, managers, industrialists, architects, journalists, and artists: a study in psychiatric outpatients," 85 J. Affect Disord 201-6.

American Bar Association Statistics (2016) Lawyer demographics in the Year 2016. Available at: https://www.americanbar.org/content/dam/aba/administrative/ market_research/lawyer-demographics-tables-2016.authcheckdam.pdf

Australian Burerau of Statistics (2015) Australian Standard Geographical Classification (ASGC). Canberra: Australian Bureau of Statsitics. Available at: http://www.abs.gov.au/AUSSTATS/abs@.nsf/DetailsPage/3218.0201415?OpenDocument

Australian Bureau of Statistics (2011) Wage and Salary Earner Statistics for Small Areas, Time Series 2010-2011. Canberra: Australian Burerau of Statsitics. Available at: http://www.abs.gov.au/ausstats/abs@.nsf/mf/5673.0.55.003

Arnold B. L., \& J. Hagan (1992) "Careers of misconduct: The structure of prosecuted professional deviance among lawyers," 57 American Sociological Rev. 6, 771-780.

Barton, B. H. (2007) "Do judges systematically favor the interests of the legal profession?" 59 Ala. L. Rev. 453.

Bartlett, F. (2008) "Professional discipline against female lawyers in Queensland: A gendered analysis. Griffin Law Rev. 171: 301-329.

Bergin A., \& N. Jimmieson (2014) "Australian lawyer well-being: Workplace demands, resources and the impact of time-billing targets," 21 Psychiatry, Psychology and Law 427.

Bismark, M. M., Brennan, T. A., Paterson, R. J., Davis, P. B., \& Studdert, D. M. (2006). Relationship between complaints and quality of care in New Zealand: a descriptive analysis of complainants and non-complainants following adverse events. BMJ Quality \& Safety, 15(1), 17-22.

Bismark, M. M. (2016) "Lifting our gaze: An epidemiological approach to medical regulation," In M. Henaghan and J. Wall (Eds.), Law, Ethics, and Medicine: Essays in honour of Peter Skegg (pp. 123-146). Wellington, New Zealand.

Bismark, M. M., M. Fletcher, M. J. Spittal, \& D. M. Studdert (2015) "A step towards evidence-based regulation of health practitioners," 39 Australian Health Review 4, 483-485.

Bismark, M. M., M .J. Spittal, T. M. Plueckhahn, D. M. Studdert. (2014) "Mandatory reports of concerns about the health, performance and conduct of health practitioners," 201 The Medical J. of Australia 7, 399-403.

Bismark, M. M., M. J. Spittal, \& D. M. Studdert (2011) "Prevalence and characteristics of complaint-prone doctors in private practice in Victoria," Medical J. of Australia 2528.

Bismark, M. M., M. J. Spittal, A. J. Gogos, R. L. Gruen, \& D. M. Studdert (2011) "Remedies 
sought and obtained in healthcare complaints," 220 BMJ Quality \& Safety 806-810.

Bismark, M. M, M. J. Spittal, L. C. Gurrin, M. Ward, \& D. M. Studdert (2013) "Identification of doctors at risk of recurrent complaints: a national study of healthcare complaints in Australia," BMJ Quality \& Safety in Health Care 1-9.

Briton, J. (2015) "Between the Idea and the Reality Falls the Shadow," Australia and New Zealand Legal Ethics Colloquium 5.

Brooke, D. (1997) "Impairment in the medical and legal professions," 43 J. of Psychosomatic Research 27-34.

Burstin, H. R., Johnson, W. G., Lipsitz, S. R., \& Brennan, T. A. (1993). Do the poor sue more?: A case-control study of malpractice claims and socioeconomic status. Jama, 270(14), 1697-1701.

Campbell, B. A, \& R. A. Kollman (1999) "The Lady or the Tiger? Opening the Door to Lawyer Discipline Standards," 1 Florida Coastal Law J. 231.

Carney T., F. Beaupert, M. Chiarella, B. Bennett, B. Walton, P. Kelly, \& C. Satchell (2016) Health Complaints and Regulatory Reform: Implications for Vulnerable Populations? $23 \mathrm{~J}$. of Law and Medicine, 23, 3:650-661.

Carson, C. N. (2004) The lawyer statistical report: The U.S. legal profession in 2000. Chicago: American Bar Foundation.

Christensen, C., S. Day, \& J. Worthington (1999) "Learned profession? The stuff of sherry talk: The response to Practice Rule 15?" 6 International J. of the Legal Profession 2769.

Community Law Australia (2012) Unaffordable and out of reach: The problem of access to the Australian Legal System. Available at: http://www.communitylawaustralia. org.au/wpcontent/uploads/2012/07/CLA_Report_Final.pdf

Curtis D. M, \& B. J. Kaufman (2004) "A public view of attorney discipline in Florida: Statistics, commentary, and analysis of disciplinary actions against licensed attorneys in the state of Florida from 1988-2002," 28 Nova Law Rev. 3.

Davies, M. R. (1999) "Solicitors, dishonesty and the solicitors disciplinary tribunal," 6 International J. of the Legal Profession 141-174.

Fortney, S., \& T. Gordon (2013) "Adopting law firm management systems to survive and thrive: A study of the Australian approach to management-based regulation," Hofstra Univ. Legal Studies Research Paper No. 13-02.

Grech, A., \& K. Morrison (2007) "Slate \& Gordon: The listing experience," 22 Georgetown J. of Legal Ethics 535-540.

Haller, L. (2003) "Dirty linen: The public shaming of lawyers" 10 International J. of the Legal Profession 3, 281-313.

Haller, L. (2010) "Professional discipline for incompetent lawyers? Developments in the UK and Australia," 17 International J. of the Legal Profession 1, 83-113.

Haller, L. (2012) "Australian discipline: The story of Issac Brott," 15 Legal Ethics 2, 197241.

Hatamyar, P. W., \& K. M. Simmons (2004) "Are women more ethical lawyers? An empirical study," 31 Florida State Univ. Law Rev. 785.

Hickson, G. B., C. F. Federspeil, J. W. Pichert, C. S. Miller, J. Gauld-Jaeger, \& P. Bost (2002) "Patient complaints and malpractice risk," 287 JAMA 2951-7. 
Hunt, D. (2009) The Hunt Review of the regulation of legal services. England and Wales Law Society. Available at: https://www.lsc.qld.gov.au/_data/assets/pdf_file /0016/260035/The-Hunt-Review-of-the-Regulation-of-Legal-Services-NZ-Dec2009.pdf

Jena, A. B., S. Seabury, D. Lakdawalla, \& A. Chandra (2011) "Malpractice risk according to doctor specialty," 365 New England J. of Medicine 629-636.

John, G. (2014) Independent comparative case review. Solicitors Regulation Authority. Available at: http://www.sra.org.uk/documents/SRA/equality-diversity/independentcomparative-case-review-iccr-gus-john.pdf

Kennedy, I., R. Howard, B. Jarman, \& M. Maclean (2000) The Inquiry Into the Management of Care of Children Receiving Complex Heart Surgery at the Bristol Royal Infirmary. Interim Report: Removal and Retention of Human Material. Central Office of Information.

Kohatsu N. D., D. Gould, L. K. Ross, \& P. J. Fox (2004) "Characteristics associated with physician discipline: a case-control study," 164 Arch Intern Med 653-8.

Kritzer, H. \& N. Vidmar (2015) "When the Lawyer Screws Up: A Portrait of Legal Malpractice Claims and their Resolution," Duke Univ. Law School Working Paper.

Kritzer, H. \& N. Vidmar (2018) When the Lawyer Screws Up: Improving Access to Justice for Legal Malrpactice Victims. University Press of Kansas.

Law and Justice Foundation of New South Wales (2014) Lawyer availability and population change in regional, rural and remote areas of New South Wales. Available at: http://www.lawfoundation.net.au/ljf/site/articleIDs/6483474887556F6FCA257DAA0 01D6AA1/\%24file/Lawyer_availability_RRR.pdf

Law Society of New South Wales (2013) Inside In-House Legal Teams Report on a Survey of Corporate and Government Lawyers. Available at: https://www.lawsociety.com.au /cs/groups/public/documents/internetcontent/71172 .pdf

Law Society of New South Wales and Urbis (2015) 2014 Law Society National Profile Final Report. Available at: https://www.lawsociety. com.au /cs/groups /public /documents/internetcontent/1005660.pdf

Levin, L. C. (1998) "The emperor's clothes and other tales about the standards for imposing lawyer disciplince sanctions,"48 American Univ. Law Rev. 1-84.

Levin, L. C. (2004) "The ethical world of solo and small law firm practitioners," 41 Houston Law Rev. 309-392.

Levin, L. C. (2012) "Misbehaving Lawyers: Cross-Country Comparisons" 15 Legal Ethics 2, 357-377.

Levin, L. C., C. Zozula, \& P. Siegelman (2013) "A study of the relationship between bar admissions data and subsequent lawyer discipline," Law School Admissions Council.

Levin, L. C. (2016) "Regulators at the margins: the impact of malpractice insurers on solo and small firm lawyers." Connecticut Law Rev. 49, 553-612.

Levinson W., D. L. Roter, J. P. Mullooly, V. T. Dull, \& R. M. Frankel (1997) "Physicianpatient communication: the relationship with malpractice claims among primary care physicians and surgeons," 277 JAMA 553-9.

Levinson, W., \& N. Lurie (2004) "When most doctors are women: What lies ahead?" 141 Ann Intern Med 6:471-474. 
MacGregor, J., \& T. Vail (2016) Profile of Legal Malpractice Claims: 2012-2015. American Bar Association Standing Committee on Lawyers' Professional Liability.

Mello, M. M., S. K. Senecal, Y. Kuznetsov, \& J. S. Cohn (2014) "Implementing hospitalbased communication--and-resolution programs: Lessons learned in New York City," 33 Health Affairs 1, 30-38.

Mello, M. M., A. Chandra, A. A. Gawande, \& D. M. Studdert (2010) "National costs of the medical liability system," Health Affairs 29:1569-77.

Moore, J., D. Buckingham, \& K. Diesfeld (2015) "Disciplinary tribunal cases involving New Zealand lawyers with physical or mental impairment 2009-2013," 22 Psychiatry, Psychology and the Law 5, 649-672.

Morrison J., \& P.Wickersham (1998) "Physicians disciplined by a state medical board," 279 JAMA 1889-93.

Mundy, T., A. Kennedy, \& J. Nielsen, Eds. (2017) The place of practice: Lawyering in rural and regional Australia. Federation Press, Leichhardt, Australia.

Omari, M., \& M. Paull (2013) "Shut up and bill: Workplace bullying challenges for the legal profession," 20 International J. of the Legal Profession 2, 141-160.

Papadakis M. A., A. Teherani, M. A. Banach, T. R. Knettler, S. L. Rattner, D. T. Stern, J. J.

Veloski, \& C. S. Hodgson (2005) "Disciplinary action by medical boards and prior behavior in medical school" 353 N Engl J. Med 2673-82.

Parker, C. (2004) "Law firms incorporated: How incorporation could and should make firms more ethically responsible," 23 The Univ. of Queensland Law J. 2, 347-380.

Parker, C., T. Gordon, \& S. Mark (2010) "Regulating law firm ethics management: An empirical assessment of an innovation in regulation of the legal profession in New South Wales," 37 J. of Law and Society 3, 466-500.

Ramos, M. R. (1996) "Legal and law school malpractice: Confessions of a lawyer's lawyer and law professor," 57 Ohio State Law J. 3: 863-937.

Rhode, D. L. (1985) "Moral Character as a Professional Credential," 94 Yale Law J. 491.

Rolph, J. E., J. L. Adams, \& K. A. McGuigan (2007) "Identifying malpractice-prone doctors," 4 J. of Empirical Legal Studies 125-153.

Rueschemeyer, D. (1983) Professional autonomy and the social control of expertise. In R.Dingwall and P. Lewis (Eds.) The Sociology of the Professions: Lawyers, Doctors and Others (pp. 38-58). London: MacMillan.

Semple, N. (2013) "Access to justice: Is legal services regulation blocking the path?" 20 International J. of the Legal Profession 3: 267-283.

Shinnick, E., F. Bruinsma, \& C. Parker (2003) "Aspects of regulatory reform in the legal profession: Australia, Ireland and the Netherlands," 10 International J. of the Legal Profession 237-267.

Sloan F., P. Mergenhagen, W. Burfield, R. Bovbjerg, \& M. Hassan (1989) "Medical malpractice experience of physicians. Predictable or haphazard? 262 JAMA 3291-7.

Sparrow, M. K. (2000). The regulatory craft. Harvard University, Cambridge, USA.

Spittal, M. J., D. M. Studdert, R. Paterson, \& M. M. Bismark (2016) "Outcomes of notifications to health practitioner boards: a retrospective cohort study," 14 BMC Medicine 198. 
Spittal, M. J., M. M. Bismark, \& D. M. Studdert (2015) "The PRONE score: an algorithm for predicting doctors' risks of formal patient complaints using routinely collected administrative data," BMJ Quality \& Safety 24:360-368.

Studdert, D. M, M. M. Bismark, M. M. Mello, H. S. Singh, \& M. J. Spittal (2016) "Prevalence and characteristics of doctors prone to malpractice claims," $374 \mathrm{New}$ England J. Medicine 354-362.

Studdert, D. M., Thomas, E. J., Burstin, H. R., Zbar, B. I., Orav, E. J., \& Brennan, T. A. (2000). Negligent care and malpractice claiming behavior in Utah and Colorado. Medical care, 250-260.

Taragin, M. I., A. P. Wilczek, M. E. Karns, R. Trout, \& J. L. Carson (1992) "Physician demographics and the risk of medical malpractice,” 93 Am J. Med 537-42.

Tibble, H. M., N. S. Broughton, D. M. Studdert, M. J. Spittal, N. Hill, J. M. Morris, \& M. M. Bismark (2017) "Why do surgeons receive more complaints than their physician peers?” ANZ J. of Surgery.

Unwin, E., K. Woolf, C. Wadlow, \& J. Dacre (2014) "Disciplined doctors: Does the sex of a doctor matter? A cross-sectional study examining the association between a doctor's sex and receiving sanctions against their medical registration,” BMJ Open 4:1-9.

Victorian Legal Services Board and Commissioner (2016). Annual Report 2016. Available at: http://the LSBC.vic.gov.au/documents/Report-Victorian-Legal_Services _Board_and_Commissioner_annual_report_2016.pdf 


\section{APPENDIX}

Box 1: Jurisdiction and Functions of the Victorian Legal Services Board and Commissioner

\begin{tabular}{|c|c|c|}
\hline & Legal Services Board & Legal Services Commissioner \\
\hline $\begin{array}{l}\text { Statutory } \\
\text { Objectives }\end{array}$ & $\begin{array}{l}\text { - Ensure the effective regulation of the } \\
\text { legal profession and the maintenance of } \\
\text { professional standards. } \\
\text { - } \\
\text { Address concerns of clients and lawyers } \\
\text { as well as provide for the protection of } \\
\text { consumers of legal services. } \\
\text { - Ensure management of trust accounts. }\end{array}$ & 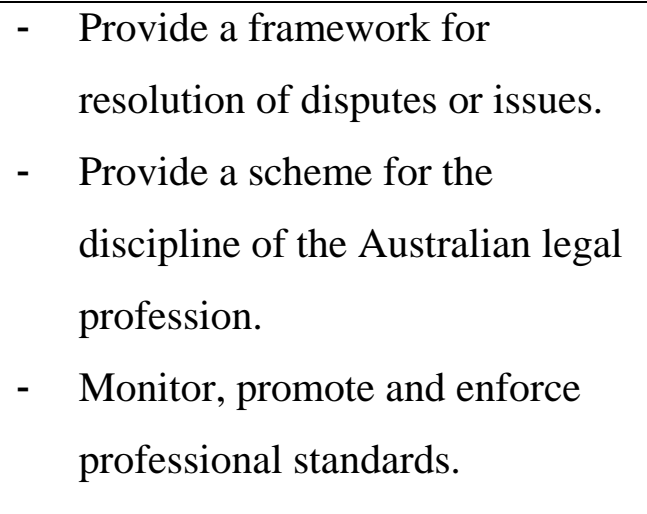 \\
\hline $\begin{array}{c}\text { Core } \\
\text { Functions }\end{array}$ & $\begin{array}{l}\text { - Maintain Register of Lawyers and Law } \\
\text { Practices and Register of Disciplinary } \\
\text { Action. } \\
\text { - } \quad \text { Manage practicing certificates, including } \\
\text { ability to impose conditions on legal } \\
\text { practice. } \\
\text { - } \quad \text { Oversee and audit trust accounts. }\end{array}$ & $\begin{array}{ll}\text { - } & \text { Receive and handle complaints } \\
\text { - } & \text { Resolve costs disputes. } \\
\text { - } & \text { Educate and inform the Victorian } \\
& \text { legal profession and community. }\end{array}$ \\
\hline Powers & $\begin{array}{ll}\text { - } & \text { Administer funds. } \\
\text { - } & \text { Register lawyers. } \\
\text { - } & \text { Issue, suspend or cancel practicing } \\
& \text { certificates. } \\
\text { - } & \text { Intervene in a practice. }\end{array}$ & $\begin{array}{l}\text { Issue binding determinations } \\
\text { where disputed amount is below } \\
\$ 10,000 \text {. }\end{array}$ \\
\hline
\end{tabular}


Box 2: Complaint Issue Types and Sub-Issues

\begin{tabular}{|c|c|}
\hline Complaint Issue Type & Complaint Sub-Issues \\
\hline Communication & $\begin{array}{l}\text { Rudeness } \\
\text { Threatening behavior } \\
\text { Poor or no communication }\end{array}$ \\
\hline Competence and diligence & $\begin{array}{l}\text { Poor advice and case handling } \\
\text { Delays } \\
\text { Poor record management }\end{array}$ \\
\hline Compliance & $\begin{array}{l}\text { Failure to comply with regulatory requirements } \\
\text { Failure to respond to regulator } \\
\text { Practicing certificate issues }\end{array}$ \\
\hline Costs & $\begin{array}{l}\text { Disclosures regarding costs } \\
\text { Billing issues } \\
\text { Overcharging }\end{array}$ \\
\hline Ethical matters & $\begin{array}{l}\text { Confidentiality } \\
\text { Fraudulent and misleading conduct } \\
\text { Conflict of interest } \\
\text { Inappropriate undertakings } \\
\text { Communication with another lawyer's client } \\
\text { False advertising } \\
\text { Abuse of process } \\
\text { Ceasing to act } \\
\text { Instructions issue } \\
\text { Failure to pay third party } \\
\text { Failure to comply with court orders }\end{array}$ \\
\hline Personal conduct & $\begin{array}{l}\text { Inappropriate personal and interpersonal behavior } \\
\text { Relating to sexual impropriety }\end{array}$ \\
\hline
\end{tabular}




\begin{tabular}{|l|l|}
\hline & Discrimination and criminal activity \\
\hline Trust accounts & Misuse of trust account money \\
\hline Other & $\begin{array}{l}\text { Concerns regarding Victorian Legal Aid } \\
\text { Concerns outside of the LSBC jurisdiction }\end{array}$ \\
\hline
\end{tabular}

Table 1: Characteristics at Baseline of All Lawyers in Victoria and Lawyers Subject to a Complaint, 2005-2015

\begin{tabular}{|c|c|c|}
\hline Characteristics & $\begin{array}{c}\text { All lawyers } \\
\text { Percent } \\
(n=20,090)^{*}\end{array}$ & $\begin{array}{c}\text { Lawyers with } \\
\text { complaints } \\
\text { Percent } \\
(n=4,180)^{\ddagger}\end{array}$ \\
\hline \multicolumn{3}{|l|}{ Sex } \\
\hline Female & 50 & 31 \\
\hline Male & 50 & 69 \\
\hline \multicolumn{3}{|l|}{ Age } \\
\hline 26-35 years & 59 & 34 \\
\hline 36-45 years & 19 & 23 \\
\hline 46-55 years & 15 & 30 \\
\hline 56-65 years & 7 & 14 \\
\hline \multicolumn{3}{|l|}{ Location of practice } \\
\hline Urban & 93 & 87 \\
\hline Non-Urban & 7 & 13 \\
\hline \multicolumn{3}{|l|}{ Trust Account Authority } \\
\hline No & 83 & 53 \\
\hline Yes & 17 & 47 \\
\hline \multicolumn{3}{|l|}{ Type of practice } \\
\hline Incorporated Legal Practice & 16 & 22 \\
\hline Traditional Law Firm & 56 & 72 \\
\hline In-house Counsel & 22 & 3 \\
\hline Community Legal Centre & 7 & 3 \\
\hline
\end{tabular}


Small (1-10 lawyers)

Medium (11-100 lawyers)

Large (>100 lawyers)

* Percentages were calculated with the number of available observations used as the denominator. $n=17,920$ for type of legal practice: data were missing for 2,170 (10.8\%) lawyers; and $n=17,944$ for size of legal practice: data were missing for 2,146 (10.7\%) lawyers.

${ }^{\dagger}$ Percentages were calculated with the number of available observations used as the denominator. $n=3,751$ for type of legal practice: data were missing for 429 (10.3\%) lawyers; and $n=3,752$ for size of legal practice: data were missing for 428 (10.2\%) lawyers. 
Table 2: Characteristics of Complaints

\begin{tabular}{|c|c|c|}
\hline Characteristics & Number & Percent \\
\hline Complaint & 15877 & 100 \\
\hline \multicolumn{3}{|l|}{ Source of Complaint } \\
\hline Client or member of the public & 14462 & 91 \\
\hline Peer & 1081 & 7 \\
\hline Legal regulatory authority & 344 & 2 \\
\hline \multicolumn{3}{|l|}{ Area of law* } \\
\hline Family & 3705 & 24 \\
\hline Property & 2851 & 19 \\
\hline Wills and Estates & 2040 & 13 \\
\hline Personal injury & 1841 & 12 \\
\hline Commercial & 1755 & 12 \\
\hline Criminal & 986 & 7 \\
\hline Debt collection & 751 & 5 \\
\hline Other & 1270 & 8 \\
\hline Complaint Issue $^{\ddagger}$ & 21938 & 100 \\
\hline \multicolumn{3}{|l|}{ Type of Complaint Issue ${ }^{+}$} \\
\hline Costs & 7745 & 36 \\
\hline Competence and Diligence & 4715 & 22 \\
\hline Ethical Matters & 4519 & 21 \\
\hline Communication & 2092 & 10 \\
\hline Trust accounts & 1750 & 8 \\
\hline Compliance Matters & 622 & 3 \\
\hline Personal Conduct & 39 & 0.2 \\
\hline Other & 44 & 0.2 \\
\hline Closed Complaint Issue $^{\wedge}$ & 21859 & 100 \\
\hline \multicolumn{3}{|l|}{ Outcome $^{\ddagger}$} \\
\hline Dismissed/not resolved & 16477 & 76 \\
\hline Resolved & 3749 & 17 \\
\hline Misconduct finding & 1476 & 7 \\
\hline
\end{tabular}

* Percentages calculated with n=15,199 available observations as the denominator. Data missing for area of law for $4 \%$ of complaints $(n=688)$.

${ }^{\ddagger}$ Complaint type described for $\mathrm{N}=21,938$ complaint issues, as one complaint may contain multiple complaint issues.

${ }^{+}$Percentages calculated with $n=21,526$ available observations as the denominator. Data Missing for type of complaint for $2 \%$ of complaint issues $(n=412)$. Percentages do not sum to 100 due to rounding.

^ Complaint outcome not available for $\mathrm{N}=79$ complaint issues which remained open at the end 
of study period.

${ }^{\ddagger}$ Percentages calculated with $n=21,702$ available observations as the denominator. Data missing for outcome of $1 \%$ of closed complant issue $(n=157)$.

This article is protected by copyright. All rights reserved. 
Table 3: Multivariate Odds of Complaints and Misconduct Findings for Lawyers in Victoria, 2005-2015

\begin{tabular}{|c|c|c|c|c|c|c|}
\hline \multirow[b]{2}{*}{ Characteristic } & \multicolumn{3}{|c|}{ Complaints } & \multicolumn{3}{|c|}{ Misconduct Outcome } \\
\hline & $\begin{array}{l}\text { Odds } \\
\text { Ration }\end{array}$ & $\begin{array}{l}95 \% \\
\text { Confidence } \\
\text { Interval }\end{array}$ & p-value & $\begin{array}{l}\text { Odds } \\
\text { Ratio }\end{array}$ & $\begin{array}{l}95 \% \\
\text { Confidence } \\
\text { Interval }\end{array}$ & p-value \\
\hline \multicolumn{7}{|l|}{ Sex } \\
\hline Female (Ref) & 1.00 & & & 1.00 & & \\
\hline Male & 1.49 & $1.37,1.62$ & $<0.001$ & 1.93 & $1.48,2.52$ & $<0.001$ \\
\hline \multicolumn{7}{|l|}{ Age } \\
\hline 26-35 years (Ref) & 1.00 & & & 1.00 & & \\
\hline 36-45 years & 1.20 & $1.10,1.31$ & $<0.001$ & 1.47 & $1.08,2.00$ & 0.014 \\
\hline 46-55 years & 1.55 & $1.41,1.70$ & $<0.001$ & 1.69 & $1.22,2.34$ & $<0.001$ \\
\hline 56-65 years & 1.56 & $1.41,1.73$ & $<0.001$ & 1.79 & $1.27,2.51$ & $<0.001$ \\
\hline \multicolumn{7}{|l|}{ Trust Account Authority } \\
\hline No (Ref) & 1.00 & & & 1.00 & & \\
\hline Yes & 2.90 & $2.69,3.13$ & $<0.001$ & 3.44 & $2.72,4.36$ & $<0.001$ \\
\hline \multicolumn{7}{|l|}{ Location of practice } \\
\hline Urban (Ref) & 1.00 & & & 1.00 & & \\
\hline Non-Urban & 1.27 & $1.15,1.41$ & $<0.001$ & 0.89 & $0.68,1.17$ & 0.415 \\
\hline \multicolumn{7}{|l|}{ Type of Practice } \\
\hline Traditional Law Firm (Ref) & 1.00 & & & 1.00 & & \\
\hline Incorporated Legal Practice & 1.37 & $1.27,1.47$ & $<0.001$ & 1.20 & $0.97,1.48$ & 0.101 \\
\hline In-house counsel & 0.20 & $0.17,0.23$ & $<0.001$ & 0.14 & $0.08,0.26$ & $<0.001$ \\
\hline Community Legal Centre & 0.58 & $0.49,0.70$ & $<0.001$ & 0.34 & $0.11,1.03$ & 0.057 \\
\hline \multicolumn{7}{|l|}{ Size of Practice } \\
\hline Small (1-10 lawyers) & 3.37 & $3.01,3.78$ & $<0.001$ & 13.4 & $7.71,23.2$ & $<0.001$ \\
\hline Medium (11-100 lawyers) & 2.55 & $2.26,2.88$ & $<0.001$ & 3.13 & $1.67,5.85$ & $<0.001$ \\
\hline Large (100+ lawyers) (Ref) & 1.00 & & & 1.00 & & \\
\hline
\end{tabular}




\section{University Library}

\section{- M M N E R VA A gateway to Melbourne's research publications}

Minerva Access is the Institutional Repository of The University of Melbourne

Author/s:

Sklar, T;Taouk, Y;Studdert, D;Spittal, M;Paterson, R;Bismark, M

Title:

Characteristics of Lawyers Who Are Subject to Complaints and Misconduct Findings

Date:

2019-06-01

Citation:

Sklar, T., Taouk, Y., Studdert, D., Spittal, M., Paterson, R. \& Bismark, M. (2019).

Characteristics of Lawyers Who Are Subject to Complaints and Misconduct Findings.

JOURNAL OF EMPIRICAL LEGAL STUDIES, 16 (2), pp.318-342. https://doi.org/10.1111/ jels. 12216.

Persistent Link:

http://hdl.handle.net/11343/286858 